UDC 070.3-051Грушев ський:655.3.066](47722)(091)(045)

DOI: $10.31651 / 2413-8142-2020-23-78-82$

V. Telvak

PhD hab. (History), Professor at Department of World History and Special Historical Disciplines, Ivan Franko Drohobych State Pedagogical University ORCID: https://orcid.org/0000-0002-2445-968X

S. Zhuravlev

Ph. D. in Education, teacher of a public school «Kharkiv comprehensive board school of Kharkiv city council,

I-II degrees»

ORCID: https://orcid.org/0000-0003-2700-1700

\section{MYKHAILO HRUSHEVSKY'S EDITORIAL PROJECTS FOR PEASANTS: IDEOLOGY, TOPICS, PERCEPTION}

The article analyses the ideology, content and public perception of the newspapers «Selo» and "Zasiv» edited by M. Hrushevsky. It has been proven that newspapers gained considerable popularity both among the intelligentsia and the common people at that time. The conclusions state that $M$. Hrushevsky's publishing projects, that were aimed at the peasant audience, became a significant component of the Ukrainian socio-political movement in the Dnipro Ukraine in the early twentieth century.

Key words: M. Hrushevsky, «Selo», «Zasiv», editorial policy, ideology, reception.

Problem statement. For a long time, M. Hrushevsky's journalism has been the focus of attention of researchers of his intellectual heritage. This is explained by the powerful influence of his public initiatives on the modernization of all aspects of the life of Ukrainians at that time. At the same time, researchers usually focus on the most influential channel of the socio-political ideology of the scientist - the «Literary-scientific herald», thus marginalizing his other publishing projects to some extent. This situation is most noticeable in the case of peasant periodicals founded and edited by $M$. Hrushevsky - the weeklies «Selo» and «Zasiv». The analysis of their ideology, content and public perception is still an urgent task for modern Hrushevsky studies.

Resaerch analysis. The «Selo» and «Zasiv» editions, founded by M. Hrushevsky, have several times become the objects of special attention of scholars. The newspaper «Selo» was analysed by I. Tkachenko as a phenomenon of the Ukrainian publishing movement [1]. He also analysed M. Hrushevsky's journalism in newspapers he edited for the peasantry [2;3]. S. Pankova reconstructed the editorial work of a prominent historian in «Selo» through the prism of memoirs and epistolary sources [4]. We need to find out the peculiarities of M. Hrushevsky's cultural policy as editor of peasant newspapers [5], as well as to study the reception of his publishing work [6].

The purpose of the article. Focusing on the particular problems of the editorial work of M. Hrushevsky as a

* The article is written in accordance with the state budget theme "Ukrainian Revolution (1917-1921 gg.): The peasant factor" (state registration number 0118U003864). publisher of the newspapers «Selo» and «Zasiv», the researchers have not managed to summarize these prominent phenomena of the Ukrainian publishing movement in the Russian Empire. Therefore, the author aims to clarify the ideology, content and public perception of the newspapers «Selo» and «Zasiv».

The statement of the basic material. The idea of publishing a newspaper for the widest circles of the Ukrainian community in the Romanov empire arose in the intelligentsia immediately after the abolition of notorious language bans after the revolutionary events of 1905. Hrushevsky substantiated the role and concept of peasant magazines [7, 327]. A year later, in the article «Our Newspaper» M. Hrushevsky developed his idea: «When there is a wider circle of readers who would fancy a more popular presentation of the material, a second, popular edition for peasants will be launched at our newspaper» $[8,3]$.

Dnipro intellectuals shared the views of Hrushevsky. The well-known personality of the Ukrainian community in St. Petersburg, Petro Stebnytsky, was especially concerned with the founding of the peasant magazine. In a letter to M. Hrushevsky in 1907, he wrote: «I am strongly convinced that we cannot turn our attention away from the village even for a moment and that we must exert all our efforts to publish an independent peasant newspaper» $[2,345]$. He expressed similar ideas in letters to the famous patron of the Ukrainian press Yevgenii Chykalenko, stating that «...middle class intelligentsia can be brought up in the German language, but the peasantry - only in the native language, as long as it has not got rid of it...if you do not bring up intelligentsia from the peasantry, they will not care about anything but land» $[9,57-58]$.

Thus, when M. Hrushevsky decided to implement the project of peasant periodicals, this news found general approval in the environment of the Dnipro intelligentsia. Vyacheslav Lypynskyi in a letter to Vasily Domanitskyi emphasized: «I learned from the «Rada» that the «Selo», an illustrated peasant weekly, will be published soon, however, I do not know more - I guess it is Professor's [M. Hrushevsky - ed.] idea. In any case, this is a crucially necessary thing, and it seems to me that it should be supported with all our might, otherwise we can lose connection with the peasants and we will not be able to catch up with it for decades. [...] Peasant weekly is the urgent need that must unite all the best Ukrainian forces» [10, 559-560].

M. Hrushevsky's plan to issue periodicals for Ukrainian peasants was realised on September 3, 1909, when the first issue of the «Selo» newspaper was published. The chief editor in the introductory article «To Our Readers» outlined the purpose and objectives of the new newspaper. At the same time, he emphasized the educational mission of the magazine: «Wherever the peasantry, the workers and the whole people are intelligent, enlightened, the better, the easier, the happier lives for everyone together and for everyone in particular they have. Less ignorance - fewer lies, harm, damage. If one wants the good thing for his/her land, people, one must take care of himself/herself, be enlightened, intelligent, but also take care of the people, community, and people around him to be as intelligent and enlightened 
as possible. This can be provided by the school, the book, the newspaper. We also want to help with our newspaper [...]» [11,234].

The «Selo» was published weekly, on Thursday, it had 8 pages. Once a month, there was a 16 pages issue. The chosen day of the newspaper (Thursday) was not random, because the editors' principle was that the reader could already read it on Sunday. The subscription price for a year was 1 rub. 60 kopiikas, for half a year -1 rub., for three months -60 kopiikas. A separate issue of the newspaper cost 5 kopiikas. The newspaper had to be printed in the First Kyiv Artel of the printing business. In 1910 the subscription price was different: for a year 2 rub., six months -1 rub. 10 kopiikas, for three months 60 kopiikas. Interestingly, the first issue of the newspaper was sent for free, and subsequently, every first issue of the newspaper sent to new subscribers was free of charge.

The «Selo» subscription announcement also indicated that subscribers would be able to get free additional gifts, such as the illustrated «Selo Calendar». At the end of 1909, the editorial board placed an announcement regarding the subscription for the 1910 edition in the issue № 17 of the «Selo», stating that the weekly was intended mainly for farmers and workers. It also indicated that «Selo» will submit articles and news about modern life in Ukraine, Russia and abroad. The newspaper promised to publish reports from villages and cities, paying particular attention to the educational and economic movement in the countryside, reporting on performances, lectures, parties, opening libraries, trade shops, loan and agricultural associations, trade unions of workers and more. «Selo» would also answer the questions of the subscribers, provide the advice of specialists in economic, legal, medical issues, as well as in economic and educational matters. For this purpose, the newspaper engaged many well-known Ukrainian scholars and writers from both sides of Zbruch.

Anna Yampolska, a friend of M. Hrushevsky from high school years, was the official editor-publisher from the beginning of the publication of «Selo». She performed her duties until April 1910. After two arrests of A. Yampolska, I. Malich was invited to take the post instead. From the beginning of April in 1910 A. Yampolska was only the publisher of the newspaper. However, I. Malich soon started working for «Rada», and his place was taken by V. Tovstonis, though on interesting terms. He agreed to stay imprisoned in the police station instead of paying the fines for half of the administrative punishment. This allowed to double the savings on fines and avoid a significant undermining of the budget of the publication.

Important materials were published under the main headings: «In a week», «From Ukrainian life», «From foreign Ukraine», «News from the capital». Almost in every issue, there were agricultural tips ( «How to cultivate arable land», «Plowmen tools», «How to store potatoes», «Should you keep goats on the farm», «How to increase the bread harvest»), submitted by A. Ternichenko, V. Korolev, Ye. Chikalenko, as well as the sections: «Replies to subscribers», «Laughs», «Posts». The weekly chronicle and column «From Ukrainian Life» was led by M. Hechter, who «managed to submit on the one column $15-20$ reports, which in whole made an impression of the act of accusation against the tsarist authorities» $[12,31]$. P. Stebnytskyi was a constant observer of the «News from the capital», M. Zaliznyak led the column «From foreign Ukraine», and after his arrest V. Doroshenko overtook it. M. Shapoval and $\mathrm{Yu}$. Tishchenko submitted reviews of world news. The heterogeneous content of the weekly was interesting to readers, who, while waiting for important agricultural tips, were simultaneously informed about key events in the social and political life of divided by borders Ukraine.

For M. Hrushevsky, who was one of the most active contributors to «Selo», the newspaper became one of the important means of broadcasting Ukrainian life at that time, raising national consciousness, and shaping socio-political thought. The scientist published 84 articles in 76 issues of the newspaper during 1909-1911. In addition to the introductions, he presented a gallery of historical portraits, images of leaders of the national movement and Ukrainian literary writing. Readers were presented with the history of Ukraine through vivid stories of great events of the past, a series of historical cities and monuments of Ukraine and more. As an educator, he was hurt by the ban on Ukrainian-language schooling on the lands under the Russian rule. He dedicated a lot of his publications specifically to this problem. Recognizing that competitions for the Ukrainianlanguage school in the Dnipro area will remain a priority of the society for a long time, M. Hrushevsky published those articles in a separate thematic collection «On the Ukrainian Language and the Ukrainian School» (1912).

Particular attention should be paid to the clear and imaginative language of M. Hrushevsky's articles. He spoke on equal terms with a common peasant while discussing the pressing problems of his life. The scientist demonstrated the talent of a promoter of science, combining the seriousness of tone with the imagery of speech in his style. S. Efremov wrote about it: «His very style, slow and a little difficult in scientific works, changes in journalism at once, acquiring flexibility, brilliance and diversity» [13, 171]. Mykola Voroniy shared similar appreciation: "When I was last year in the village in Chernihiv region, I had the opportunity to see the impatient peasants who were paying for «Selo», waiting for each new issue, which they read together aloud in the street, explaining some difficult issues to each other. Those who think that the peasant is reluctant to read about important, unfamiliar things to him are mistaken. They say, a peasant does not want to overload his head, well, I was pleasantly surprised to see how much interest the peasants expressed in historical and journalistic articles of Prof. Hrushevsky» [14, 2].

What was the reception of different categories of readers to M. Hrushevsky's editorial work? Firstly, the fascinating reaction of fellow scientists from the Ukrainian democratic camp, who rightly pointed out that it was Hrushevsky who had the power to realize the intellectual dream of a peasant newspaper. M. Kotsyubynsky shared his impressions of the first peasant newspaper with its editor: «I just read the first issue of «Selo» and I cannot wait to share my impressions with you. I am stunned. The issue is very interesting, articles, especially some, are written not only in a simple but also in a talented 
language and you read them with great interest. Appearance, illustrations - all this makes the most useful experience. We have not had such a peasant magazine. [...] In general, I want to congratulate you and all those who care about our nation with a great purchase, as before it was still only a dream (a good peasant newspaper). But now the dream has come true» [15, 292].

The peasants themselves welcomed the appearance of the first newspaper in their native language. Their excitement was reflected in numerous letters sent to the editor-in-chief. To give an example, a letter to $\mathrm{M}$. Hrushevsky by a peasant D. Semenchenko: «Dear editor! It feels as if we lived in the dark until recently. We have not seen or heard anything interesting or useful in our language in books or newspaper before. It was a difficult life, with rotten air. But we survived all that, because the fresh air blew, the heavy spirit was dispelled! The village now resonates with cheerful talks, we can hear our native language and Ukraine-mother is smiling now because her sad children - the peasants - became more cheerful. The «Ridnyi krai» was first, now we have «Selo». A peasant reads it now and with a cheerful face he addresses his illiterate brother, and he cries out in astonishment: «I understand! Everything is clear! ...», and both are happy, both are happy...» $[1,97]$. One $20-$ year-old girl in the letter to the newspaper called the magazine «the leading star in life» $[16,223]$.

As you can see, the common reader perceived the emergence of «Selo» as a true gift. M. Hrushevsky himself wrote about it: «And the common readers of the people appreciated it [Selo]; the editorial staff did not lack the «friends-readers» from the peasants and workers, who, in the event of an ordeal, declared to the newspaper their gratitude and sincere trust. The interest among the peasants to «Selo» was great; I know the facts where the peasants deliberately went to the railway station thirteen miles just to take «their newspaper» to have it sooner in their hands « $[17,184]$. Finally, the popularity of «Selo» is evidenced by the number of subscribers more than 2000, which made the newspaper the most read Ukrainian periodical in the Dnipro during the period between the two revolutions.

The immense popularity of «Selo» and «Zasiv» among the Ukrainian folk and intellectual circles was the reason for the specific «attention» to the publications by the tsarist censorship. It should be noted that the representatives of the administration quite seriously assessed this threat to their influence in the village. Therefore, numerous financial punishments were imposed at the publication for the explicit and fictitious miscalculations of publishers' editorial policies. When there was nothing to fine for, there were prohibitions on subscriptions to «Selo». Governors' circulars were directed its banning, with orders not to allow the newspaper to be delivered to subscribers and to destroy and burn those copies that had been received. Other orders recommended to observe the teachers who had subscribed to «Selo» and to sack them from their posts. The Katerynoslav governor even requested the Kyiv governor whether «Selo» was officially authorized or illegal. M. Hrushevsky himself was writing the readers of the «Literary-Scientific Herald» with bitter irony about these persecutions: «The fact is that no Ukrainian publishing house has been so strictly punished: apart from the obvious repressions and punishments that this newspaper suffered, it has been oppressed from the beginning of its existence. It was «secretly» forbidden by all authorities and departments, starting from the order to not deliver the newspaper to the addressees but to send them to the office of the governor. It seems that only the «management of the state horse-breeding» and the «department of Empress Maria» did not bother to issue special circulars which forbade the subscription of the «Selo» to its subordinates» $[17,184]$. It should also be mentioned that the issue of the persistent persecution of peasant newspapers edited by him is constantly present on the pages of M. Hrushevsky's diary, which described this «attention» as «irrepressible darkness of the reaction that covers the horizons without leaving any light» $[18,118]$.

As a result of the mass persecution, in early 1911, M. Hrushevsky announced the closure of the newspaper. On behalf of all the staff of the newspaper, he addressed the readers from the last pages: «It is difficult to publish a fair magazine in general now, and even more difficult in the Ukrainian language, and even worse - for peasant Ukrainians. [...] There is no such newspaper as ours» $[11,280]$. Finally, he announced the new newspaper «Zasiv» as a continuation of the newspaper «Selo» and those of its traditions, that were established «in such a short time since the publication of the first peasantworker newspaper in Ukrainian». M. Hrushevsky informed his readers that those subscribers who paid for the yearly subscription of «Selo» would receive «Zasiv» at no extra charge. After the final closure of the newspaper at the «Literary and Scientific Herald», M. Hrushevsky once again expressed his genuine concern about the attitude to the Ukrainian periodicals in the Romanov empire, openly emphasizing on the reasons for the closure of this important means of raising national and public awareness [17].

Therefore, «Selo» was replaced by «Zasiv». Ukrainians were granted permission for its publishing in advance, foreseeing the inconsolable fate of the Ukrainian peasant periodicals. Through the new magazine «Zasiv» (1911-1912) M. Hrushevsky addressed subscribers twice - in the first issue and six months after that. In both articles, he regretted the closure of the weekly «Selo» and urged the peasants-subscribers to be more active so that at least «Zasiv» could come out. M. Hrushevsky explained difficulties with publishing Ukrainian newspapers. He pointed out at the administration actions and certain secret bans that persecuted both weeklies [19, 1-2]. Unfortunately, the publishing history of the "Zasiv», although it significantly increased the share of discussion of purely economic issues by reducing the content of sociopolitical journalism, was like its predecessor. The tsarist administration quickly realized that «Zasiv» was a more deliberate continuation of «Selo» and resumed repression, with constant financial punishment which led to the closing of this newspaper [3].

The conclusions. Thus, M. Hrushevsky's publishing projects aimed at the peasant audience became a prominent component of the Ukrainian socio-political movement in the Dnipro Ukraine in the early twentieth 
century. The editor of the «Selo» and «Zasiv» conveyed to the people the values of community and solidarity, pride in their history, love for their native language and respect for the cultural diversity of the inhabitants of Ukrainian lands. The reader was impressed by the seriousness with which the distinguished historian addressed him/her, as well as by his optimism, the calls to believe in his/her strength and to actively face and defeat the challenges of life. All this made «Selo» and «Zasiv» the authoritative school of national selfeducation, the enlightenment of the peasant. It had a significant influence on the fate of Ukrainians who later faced numerous challenges of the first decades of the twentieth century.

\section{Bibliography:}

1. Ткаченко I. «Село» - перша українська суспільнополітична селянська газета. Рукописна та книжкова спадщина Украӥни. 2005. Вип. 10. С. 91-104.

2. Ткаченко I. Публіцистика Михайла Грушевського на сторінках тижневиків «Село» та «Засів» як джерело з історії української селянсько-робітничої дореволюційної періодики. Рукописна та книжкова спадщина Украйни. 2015. Вип. 19. С. 344-352.

3. Ткаченко I. Видання українського народного тижневика «Засів» у Києві (1911-1912). Рукописна та книжкова спадщина Украӥни. 2004. Вип. 9. С. 29-45.

4. Панькова С. Михайло Грушевський і народна газета «Село»у світлі мемуарних та епістолярних джерел. Український історик. 2004-2005. № 3-4; 1. С. 25-46.

5. Тельвак В. Культурна політика Михайла Грушевського як редактора селянських газет. Украӥнський селянин. 2018. Вип. 19. С. 127-133.

6. Тельвак В. Науково-популярні праці Михайла Грушевського в історіографічних дискусіях початку XX століття. Дрогобииький краєзнавчий збірник. 2006. Вип. X. C. $348-358$

7. Грушевський М. Перші кроки // Грушевський М. Твори : у 50 т. Львів : Світ, 2002. Т. 1: Серія «Суспільнополітичні твори (1904-1907)». С. 323-328.

8. Грушевський М. Наша газета // Грушевський М. Твори : у 50 т. Львів : Світ, 2005. Т. 3: Серія «Суспільно-політичні твори (1907 - березень 1917)». С. 3-5.

9. Чикаленко Є., Стебницький П. Листування. 1901-1922 роки. Київ : Темпора, 2008. 628 с.

10. Липинський В. Повне зібрання творів, архів, студії. Архів. Київ-Філадельфія, 2003. Т. І. - Листування. - Т. I (А-Ж). 959 c.

11. Грушевський М. До наших читачів // Грушевський М. Твори : у 50 т. Львів : Світ, 2005. Т. 3: Серія «Суспільнополітичні твори (1907 - березень 1917)». С. 233-234.

12. Гехтер М. Спогади. Листи до М. Грушевського. Київ, $2005.64 \mathrm{c}$.

13. Єфремов С. На сторожі національної гідності. До характеристики публіцистичної діяльності М. С. Грушевського. Украӥнський історик. 1995. Ч. 1-4. С. 167 179.

14. Вороний М. «Село». Рада. 1911. № 78. С. 2.

15. Гісцова Л. Листи Михайла Коцюбинського до Михайла Грушевського. Записки НТШ. Львів, 1992. T. CCXXIV: Праці філологічної секції. С. 289-294.

16. Листування Михайла Грушевського. Київ ; Нью-Йорк : УIT, 2012. T. 6. 640 c.

17. Грушевський М. Недооцінювання // Грушевський М. С. Твори : у 50 т. Львів : Світ, 2005. Т. 2: Серія «Суспільнополітичні твори (1907-1914)». С. 183-188.

18. Грушевський М. Щоденник, 1910 р. Украйнський історик. 2002. № 1-4. С. 100-127.

19. Грушевський М. До наших читачів. Засів. 1911. № 1 . C. 1-2.

\section{References:}

1. Tkachenko, I. (2005). «Village»- the first Ukrainian publicpolitical peasant newspaper. Manuscript and book heritage of Ukraine. (issue 10), (pp. 91-104) [in Ukrainian]

2. Tkachenko, I. (2015). Publicistic works of Mykhailo Hrushevsky on the pages of weekly newspapers «Village» and «Sowing» as a source from the history of Ukrainian peasants' and workers' prerevolutionary periodicals. Manuscript and book heritage of Ukraine. (issue 19), (pp. 344-352) [in Ukrainian].

3. Tkachenko, I. (2004). The publication of the Ukrainian folk weekly «Zasiv» in Kiev (1911-1912). Manuscript and book heritage of Ukraine. (issue 9), (pp. 29-45) [in Ukrainian]. 4. Pan'kova, S. (2004-2005). Mykhailo Hrushevsky and the people's newspaper «Selo» in the light of memoirs and epistolary sources. Ukrainian Historian. (issue 3-4; 1), (pp. 25-46) [in Ukrainian].

5. Telvak, V. V. (2018). Cultural politics of Mykhailo Hrushevsky as an editor of village magazines. Ukrainian peasant. Collection of scientific works. (issue 19), (pp. 127133) [in Ukrainian].

6. Telvak, V. V. (2006). Mikhajlo Hrushevskij's popular science works in the historiographic discussions at the beginning of XX th century. Drohobych/ Regional/ Studies. (issue X), (pp. 348-358) [in Ukrainian].

7. Hrushevsky, M. (2002). The first steps: Hrushevsky M.S. Works: 50 vol. Lviv: Svit, 2002. Vol. 1: Series «Socio-Political Works (1904-1907)», (pp. 3-5) [in Ukrainian].

8. Hrushevsky, M. (2005). Our newspaper: Hrushevsky M.S. Works: 50 vol. Lviv: Svit, 2005. Vol. 3: Series «Socio-Political Works (1907 - March 1917)», (pp. 3-5) [in Ukrainian].

9. (2008) Chykalenko Ye. and Stebnytsky P. Correspondence. 1901-1922 years. Kyiv: Tempora [in Ukrainian].

10. Lypynsky, V. (2003). Complete collection of works, archive, studies. Archive. T.I. Correspondence. T. I (A-Z). Kyiv-Philadelphia [in Ukrainian].

11. Hrushevsky, M. (2005). To our readers: Hrushevsky M.S. Works: 50 vol. Lviv: Svit, 2005. Vol. 3: Series «Socio-Political Works (1907 - March 1917)», (pp. 233-234) [in Ukrainian].

12. Gechter, M. (2005). Memoirs. Letters to M. Hrushevsky. Kyiv [in Ukrainian].

13. Yefremov, S. (1995). On the guard of national dignity. To the characteristic of the journalistic activity of M. S. Hrushevsky. Ukrainian Historian. (issue 1-4; 1), (pp. 167-179) [in Ukrainian].

14. Vorony, M. (1911). «Village». Council. (issue 78), (p. 2) [in Ukrainian].

15. Giscova, L. (1992). Letters from Mikhajlo Kotsyubinsky to Mikhajlo Hrushevsky. Memoirs of the SSS. (issue CCXXIV), (pp. 272-324) [in Ukrainian].

16. (2012). The correspondence of Mikhailo Hrushevsky. Vol. 6. Kiev - New York: UIT. [in Ukrainian].

17. Hrushevsky, M. (2005). Underestimating: Hrushevsky M.S. Works: 50 vol. Lviv: Svit, 2005. Vol. 2: Series «SocioPolitical Works (1907 - 1914)», (pp. 183-188) [in Ukrainian]. 18. Hrushevsky, M. (2002). Diary, 1910. Ukrainian Historian. (issue 1-4), (pp. 100-127) [in Ukrainian].

19. Hrushevsky, M. (1911). To our readers. Seeded. (issue 1), (pp. 1-2) [in Ukrainian].

\section{В. Тельвак, С. Журавльов}

\section{СЕЛЯНСЬКІ ВИДАВНИЧІ ПРОЕКТИ МИХАЙЛА ГРУШЕВСЬКОГО: ІДЕОЛОПЯ, ПРОБЛЕМАТИКА, РЕЦЕПЦІЯ}

Постановка проблеми. У статті досліджено ідеологію, змістове наповнення та суспільне сприйняття редагованих М. Грушевським газет «Село» (1909-1911) та «Засів» (1911-1912). 
Актуальність иієї проблеми зумовлена тим, щ⿻ й надалі селянські видавничі проекти вченого є найменш знаною складовою його публічистичної спадщчини. Натомість, саме цүі видання перебували в полі особливої уваги М. Грушевського з огляду на вагомість тогочасної потреби начіонального виховання народних мас з метою їх оперативного залучення до реалізаиії актуальних завдань українства.

Метою статті $\epsilon$ з'ясування ідеології, змістового наповнення та суспільної рецеепиіі редагованих М. Грушевським газет «Село» та «Засів».

Основні результати дослідження. Виявлено, щз для М. Грушевського газети для селян стали важливими трибунами освітлення тогочасного життя українства, піднесення національної свідомості, формування суспільно-політичної думки. Через різнопланові дописи редактор транслював у народне середовище иінності соборності та солідаризму, гордощів за свою історію, любові до рідноїмови та поваги до культурного різноманіття мешканиів украӥнських земель. Читачеві імпонувала серйозність, з якою до нього звертався видатний історик, як також і пропагований ним оптимізм, заклики вірити у свої сили та діяльно сприймати виклики життя.

Досліджено рецепиію діяльності М. Грушевського на чолі редакиій селянських газет. Першою в часі була захоплююча реакиія колег ученого (М. Коцюбинський та М. Вороний) з українського демократичного табору, котрі слушно вказали, що саме львівському професору виявилося під силу втілити в життя давню інтелігентську мрію про селянську газету. Не менш піднесено появу адресованої собі першої газети рідною мовою зустріли й самі селяни, надсилаючи М. Грушевському численні подячні листи. Їхній зміст дозволяє зробити висновки, щуо читач з народу сприйняв появу «Села» та «Засіву» як правдивий подарунок. Неабияка популярність редагованих М. Грушевським селянських газет в українських народних та інтелігентських колах стала причиною специфічної «опіки» над виданнями з боку ирарської цеензури. Слід відзначити, щчо представники адміністрації доволі серйозно оцінили загрозу своєму впливу на селі, щзо йшла від редагованих М. Грушевським часописів. Тож на видання посипалися численні фінансові кари за явні та вигадані прорахунки редакиійної політики видавиів, котрі призвели до вимушеного закриття «Села», а потім $i$ «Засіву».

Висновки. Підсумовано, щуо зорієнтовані на селянську аудиторію видавничі проекти М. Грушевського стали помітною складовою украӥнського суспільно-політичного руху на Наддніпрянщині на початку XX $\mathrm{cm}$. «Село» та «Засів» були школою національного самовиховання спраглого просвіти селянина, щзо мало вагомий вплив на долю українства, котре постало перед численними викликами перших десятиліть XX cm.

Ключові слова: М. Грушевський, «Село», «Засів», редакиійна політика, ідеологія, рецепиія.

\section{УДК 930:94(436:477.83/.86)"17/18”(045) \\ DOI: 10.31651/2413-8142-2020-23-82-90}

Б. М. Янишин

кандидат історичних наук, старший науковий співробітник відділу історї Украӥни XIX- початку XX $\mathrm{cm}$. Інституту історії Украӥни НАН Украӥни

ORCID: https://orcid.org/0000-0003-0386-2530

\section{СОЦІАЛЬНО-ЕКОНОМІЧНА МОДЕРНІЗАЦІЯ ГАБСБУРЗЬКОЇ ГАЛИЧИНИ: ІСТОРІОГРАФІЯ ВИБРАНИХ АСПЕКТІВ}

Статтю присвячено аналізу сучасної украӥнської та польської історіографії з сочіально-економічнӧ̈ модернізаиії габсбурзької Галичини. 3'ясовано здобутки в дослідженні найбільш популярних напрямів $і$ проблем. Відзначено, ияо сьогодні економічні процеси вивчаються у їх шільному зв'язку з соиіальним контекстом. Це дозволяє виявити раніме не зауважений взаємовплив модернізаиійних факторів. Виокремлено перспективні напрями подальшого наукового пошуку.

Ключові слова: сочіально-економічна модернізачія, габсбурзька Галичина, українська та польська історіографія.

Постановка проблеми. Проблематика соціальноекономічної модернізації Галичини автономічної доби привертає прискіпливу увагу дослідників вже від кінця XIX ст., відколи в 1888 р. з'явився знаковий текст польського економіста С. Щепановського «Nędza galicyjska». Праця наробила чимало галасу в тогочасній публіцистиці та спеціальній літературі й по сьогодні змушує дослідників у той чи інший спосіб апелювати до змальованої в ній картини. Як відомо, «Nędza galicyjska» була суворим порахунком iз цивілізаційним та економічним відставанням Галичини: автор емоційно віднотовував слабкість промисловості, вбогість сільського господарства, анальфабетизм широких народних мас і суспільну апатію стосовно економічних викликів. Виступ С. Щепановського, заснований на статистичних даних другої третини XIX ст., невиправдано наклав тінь на оцінки стану галицької економіки 1888-1914 рр., адже від часу публікації згаданої праці в Галичині сформувалися різнорідні економічні та соціальні практики, котрі були наслідком прогресивних змін. Тож ще сучасники С. Щепановського аргументовано довели, що його тези про фатальну кондицію галицької господарки у жодному разі не можна розтягати на наступні десятиліття.

Втім полеміка 3 польським економістом набула перманентного характеру: кожне нове покоління дослідників вважало питанням честі заперечити іменитому попереднику, пропонуючи щоразу нові аргументи в осмисленні феномену галицької модернізації. Не стали винятком і наші сучасники, котрі протягом останніх тридцяти років, інтерпретуючи нововідкриті масиви джерел за допомогою різноманітного методологічного інструментарію, створили розлогу літературу стосовно соціально-економічних процесів у габсбурзькій Галичині. Солідність - як кількісна, так і якісна - цих текстів вочевидь вимагає історіографічного підсумування. Оскільки повноцінно 